\title{
プロトックス阻害型除草剂耐性植物の作出に関する 基礎研究
}

堀越守

日本農薬株式会社総合研究所

\section{Fundamental Studies on the Production of Plants Resistant to Protox Inhibiting Herbicides}

\author{
Mamoru HORIKOSHI \\ Research Center, Nihon Nohyaku Co., Ltd., \\ 345, Oyamada-cho, Kawachi-nagano, Osaka 586-0094, Japan
}

\section{は じめに}

今から 10 年ほど前, 当社ではプロトックス阻害型除草剂 に属する ET 系化合物を畑作用除草剂として開発中であっ た. 1989 年前後にはプロトックス阻害型除草剤の作用機作 が明らかとなりつつあった。また，アミノ酸生合成阻害型 除草剂耐性植物の作出が盛んに試みられていた。そこで, 自社の除草剂候補である ET 系化合物耐性植物を作出する 事を最終目標として，本研究を開始した，当時はプロトッ クス阻害型除草剤の標的酵素であるプロトックスをコード する遺伝子は，植物のみならず，いずれの生物からも単離 されていなかった。そこで，研究の方法としては，まず， 植物組織培養技術を用いてプロトックス阻害型除草剂耐性 細胞を選抜することを試みた。

\section{プロトックス阻害型除草風の作用機作}

全ての生物にはテトラピロール合成系が普遍的に存在 し，植物においてはミトコンドリアではへムが，葉緑体で はへム及びクロロフィルが，それぞれ最終的に合成される。 プロトックス阻害型除草剤を処理すると Protoporphyrin IX (Proto IX) が蓄積することが明らかとされ1)，その後の 研究で, 標的酵素は Protoporphyrinogen IX (Protogen) か ら Proto IX への酸化反応を触媒する Protoporphyrinogen oxidase (プロトックス) であることが明らかとなった ${ }^{2,3}$. プロトックス阻害型除草䯕によってプロトックスが阻害さ れると基質の Protogen が蓄積し，このProtogen が細胞質 に漏れ出し，細胞膜に結合した除草剂耐性の非特異的酸化
酵素によって酸化され, Proto IX が生成される.この Proto IX に光が当たると一重項酸素 (活性酸素の一種) が発生し, この働きで脂質の過酸化が起こク，細胞死に至る ${ }^{4,5)}$.この ような作用機作から，プロトックス阻害型除草剤は光要求 型除草剂(6) あるいは Peroxidizing 除草剂7) とも呼ばれてい る.

\section{プロトックス阻害型除草剤 ET-62311 及び ET-751 の性質}

本研究における夕バコ耐性株の選抜にはET-751 類縁体 の ET-62311 (4-chloro-3-[2,4-dichloro-5-(2-propenyloxy) phenyl]-5-difluoromethoxy-1-methylpyrazole) を用い，その 後の実験では ET-7518) (pyraflufen-ethyl，Fig. 1 及び Table 1)を用いた.ET-751 は現在エコパート®という商品名でム ギ用除草剂として農薬登録されている，ET-751 及びET62311 は共に 3-フェニルピラゾール系化合物であり, 两化 合物とも処理細胞中における Proto IX の蓄積及び in vitro におけるプロトックスの阻害を確認している99.

\section{タバコ耐性株の選抜 ${ }^{10)}$}

植物細胞は一細胞から植物体まで再生する能力，すなわ ち, 全能性を持ち, また, 植物の培養細胞は体細胞変異と 呼ばれる遺伝的多様性の宝庫であるため，植物組織培養技 術は除草剂耐性植物作出のための有用なツールとして利用 されてきた ${ }^{11)}$ ．植物組織培養技術によって様々な耐性株が 得られ，スルホニルウレア耐性タバコ ${ }^{12)}$,グリホセート耐性 タバコ ${ }^{13)}$ 及びイミダゾリノン耐性コムギ細胞 ${ }^{14)}$ 等は植物 体にまで再生されている。また，除草剂耐性細胞は，除草 


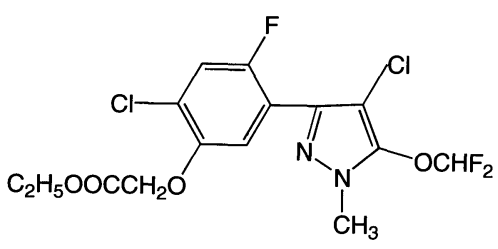

Fig. 1 Chemical structure of ET-751.

Table 1 Properties of ET-751.

\begin{tabular}{|c|c|}
\hline $\begin{array}{l}\text { Code name } \\
\text { Common name } \\
\text { Trade name } \\
\text { Chemical name }\end{array}$ & $\begin{array}{l}\text { : ET-751 } \\
\text { : pyraflufen-ethyl } \\
\text { : Ecopart }{ }^{\circledR} \text { 2\% SC (in Japan) } \\
\text { : ethyl 2-chloro-5-(4-chloro-5- } \\
\text { difluoromethoxy-1-methylpyrazol- } \\
\text { 3-yl)-4-fluorophenoxyacetate }\end{array}$ \\
\hline $\begin{array}{l}\text { Melting point } \\
\text { Molecular weight } \\
\text { Appearance } \\
\text { Water solubility } \\
\text { Vapour pressure }\end{array}$ & $\begin{array}{l}: 126.0-127.0^{\circ} \mathrm{C} \\
: 413.18 \\
: \text { pale brown, crystalline } \\
: 0.05 \mathrm{ppm}\left(25^{\circ} \mathrm{C}, \mathrm{pH} 7.0\right) \\
: 1.6 \times 10^{-8} \mathrm{mPa}\left(25^{\circ} \mathrm{C}\right)\end{array}$ \\
\hline $\begin{array}{l}\text { Acute oral toxicology } \\
\text { Fish toxicology } \\
\text { Skin irritation } \\
\text { Eye irritation } \\
\text { Mutagenicity }\end{array}$ & $\begin{array}{l}:>5000 \mathrm{mg} / \mathrm{kg}\left(\mathrm{LD}_{50} \text { for rats) }\right. \\
:>10 \mathrm{ppm}\left(\mathrm{LC}_{50} \text { at } 48 \mathrm{~h} \text { for carps) }\right. \\
: \text { non-irritant (for rabbits) } \\
: \text { slight irritant (for rabbits) } \\
: \text { negative (Ames test) }\end{array}$ \\
\hline Application rate & $\begin{array}{l}\text { : selective post-emergence control of } \\
\text { broad-leaved weeds, especially } \\
\text { Galium aparine, Matricaria inodora, } \\
\text { Lamium purpureum and Stellaria } \\
\text { media, in cereals } \\
: 10-20 \mathrm{~g} \text { a.i./ ha }\end{array}$ \\
\hline
\end{tabular}

剂耐性遺伝子の遺伝子源としても有用である。スルホニル ウレア耐性タバコ細胞から耐性型 acetolactate synthase (ALS) 遺伝子が15)，アトラジン耐性タバコ細胞から耐性型 $p s b A$ 遺伝子が ${ }^{16)}$ ，それぞれ単離されている。このような観 点から, 我々はプロトックス阻害型除草剂耐性植物の作出 を最終目標とし，まず，耐性細胞を選抜することを試みた。 タバコ葉からプロトプラストを分離し，カルスに再生さ せた. 再生させたカルスを ET-62311 存在下で培養し, 耐性 カルスを選抜した。すなわち， $1 \times 10^{10}$ 個のプロトプラスト から 50\%以上の効率でカルスを再分化させ，ET-62311の

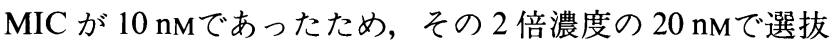
を開始した(Table 2)。およそ1 か月ごとに，より高濃度の ET-62311を含む培地に移植して選抜を継続し，最終的に $2400 \mathrm{nM}$ の ET-62311 存在下でも生育可能なカルスが 36 株 得られた。これら 36 株の中から生育速度等を考慮し, 最終 的に ETR-056, 245 及び 253 の 3 株を選抜した.この選抜に は計 16 か月を要した。これら耐性株を植物体に再生させる ことを試みたが，再生は不可能であった，選抜期間中にお けるトランスポゾンの転移等による培養変異 ${ }^{17)}$ がその原
Table 2 Selection process for resistant cell lines of tobacco callus against ET-62311.

\begin{tabular}{cc}
\hline${\text { ET-62311(nM })^{\mathrm{a})}}$ & No. of resistant cell lines $^{\mathrm{b})}$ \\
\hline 20 & 100,000 \\
30 & 50,000 \\
50 & 40,000 \\
75 & 7,200 \\
150 & 254 \\
300 & 120 \\
600 & 66 \\
1200 & 46 \\
2400 & 36 \\
5000 & 0 \\
\hline
\end{tabular}

a) Concentrations of ET-62311 used for the selection. b) Tobacco calli regenerated from $1 \times$ $10^{10}$ protoplasts were applied.

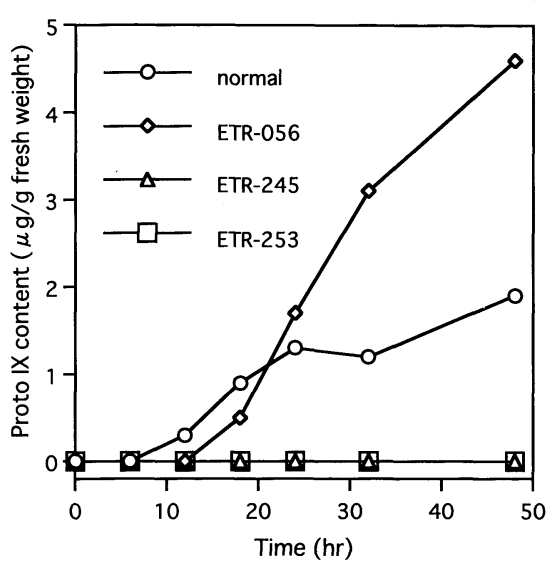

Fig. 2 Time course of Proto IX accumulation after ET62311 treatment $(1200 \mathrm{nM})$ in normal tobacco cells $(\bigcirc)$, ETR-056 $(\diamond)$, ETR-245 $(\triangle)$ and ETR-253 ( $\square)$ in liquid medium.

因であると考えられた。

\section{耐性機構の解析}

選抜された 3 株における耐性機構を生化学的に解析する ことを試みた。まず，ET-62311 処理細胞中における Proto IXの蓄積量を測定した．ET-62311を含まない培地で前培 養したカルスを ET-62311 を含む培地に移植し，暗所で培 養後，経時的にサンプリングし，Proto IX 量を測定した (Fig. 2). 感受性株では当然 Proto IX の蓄積が認められ, また，ETR-056 株では感受性株以上の Proto IX の蓄積が 認められた。一方, ETR-245 及び 253 株では Proto IX の蓄 積は全く認められなかった。

次に，各耐性株の様々な作用機作の除草剂に対する交差 耐性を比較することを試みた。除草剂としてはプロトック 又阻害型除草剂の ET-751, fomesafen 及び oxadiazon, 脂質 合成阻害剂の butachlor ${ }^{18)}$, クロロフィル合成阻害剂の 
Table 3 Cross-resistance of ET-62311 resistant cell lines to various herbicides in MS agar.

\begin{tabular}{ccccc}
\hline \multirow{2}{*}{ Herbicide } & \multicolumn{4}{c}{ MIC (nM) } \\
\cline { 2 - 5 } & Normal & ETR-056 & ETR-245 & ETR-253 \\
\hline ET-751 & 5 & $>2400$ & $>2400$ & $>2400$ \\
Fomesafen & 1 & 10 & 10 & 10 \\
Oxadiazon & 3 & 3000 & 3000 & 3000 \\
\hline Butachlor & 300 & 300 & 300 & 300 \\
Pyrazoxyfen & 250 & 250 & 250 & 500 \\
Propanil & 450 & 450 & 450 & 450 \\
Bensulfuron- & 0.025 & 0.025 & 0.025 & 0.25 \\
methyl & & & & \\
Glyphosate & 1000 & 1000 & 1000 & 4000 \\
Paraquat & 50 & 500 & 50 & 50 \\
\hline
\end{tabular}

a) MIC denotes minimum inhibitory concentration of herbicides.

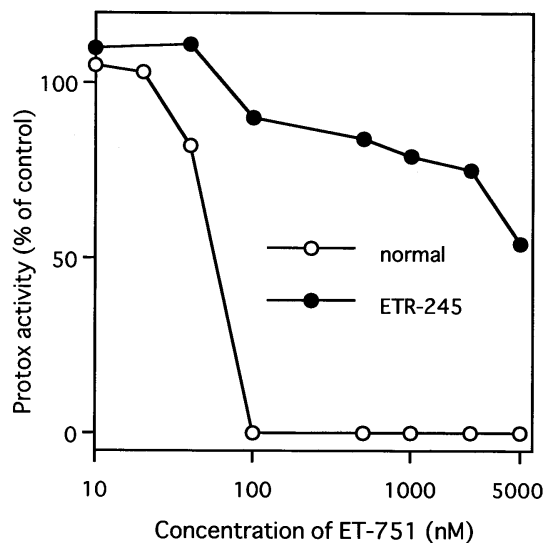

Fig. 3 The inhibitory effect of ET-751 on the Protox activities extracted from normal tobacco cells $(O)$ and ETR-245 (๑) in liquid medium.

pyrazoxyfen, 光化学系II阻害剂の propanil, ALS 阻害剂の bensulfron-methyl, 5-enolpyruvyl-shikimate-3-phosphate synthase (EPSPS) 阻害剂の glyphosate 及び光化学系 I 阻害 剂の paraquat を用いた，その結果（Table 3)，いずれの耐 性株も，いずれのプロトックス阻害型除草剂に対しても交 差耐性を示し,それに加え, ETR-056 株は paraquatに対し, ETR-253 株は pyrazoxyfen, bensulfron-methyl 及び glyphosateに対し交差耐性を示した. したがって, ETR-245 株 では Proto IXの蓄積が認められ，また，光化学系 I 阻害剂 で活性酸素を生成させる paraquatに対して交差耐性を示 すことから，活性酸素分解酵素の過剩生産 ${ }^{19)}$ が耐性に関与 していることが示唆された。一方，ETR-253 株は異なった 作用機作の複数の除草剂に対し交差耐性を示したことか ら，薬剤の取り込みの低下あるいは代謝活性の増強による 多剂耐性 ${ }^{13,20)}$ が関与していることが示唆された。一方, ETR-245 株においては様々な構造のプロトックス阻害型
除草剂に特異的に交差耐性を示したため，標的酵素である プロトックスの耐性型への変異あるいはプロトックスの過 剩生産が耐性に関与していることが示唆された。

さらに，ETR-245 株における耐性機構を明らかにするた め, 感受性株及び ETR-245 株から粗プロトックス画分を抽 出し，タンパク質量あたりのプロトックス活性を in vitro において測定することを試みた。その結果，感受性株では $2.24 \mathrm{~nm}$ Proto IX $/ \mathrm{min} / \mathrm{mg}$ タンパク質, ETR-245株では $2.93 \mathrm{nM}$ Proto IX $/ \mathrm{min} / \mathrm{mg}$ タンパク質となり，タンパク質 量あたりのプロトックス活性に大きな違いは認められな かった.そこで, 両株由来のプロトックス活性の ET-751に 対する感受性を比較することを試みた。その結果 (Fig. 3)， 感受性株由来のプロトックス活性に対する ET-751の $\mathrm{I}_{50}$

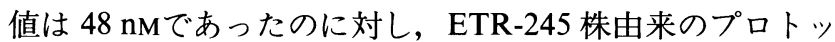
クス活性に対する ET-751の $\mathrm{I}_{50}$ 值は $5000 \mathrm{nM}$ 以上となり， R/S 比は 100 倍以上となった．したがって，ETR-245 株に おいては標的酵素であるプロトックスの耐性型への変異が 耐性に関与していることが示唆された。

\section{タバコ耐性株の分子生物学的解析 ${ }^{21)}$}

本研究の最終目標はプロトックス阻害型除草剂耐性植物 の作出であるが，前述のように，得られた耐性株を植物体 に再生することは不可能であった，そこで，耐性株から何 らかのプロトックス阻害型除草剂耐性遺伝子を単離後, 得 られた耐性遺伝子を用いて植物体を形質転換し，植物体レ ベルで耐性を発現させるという方向に研究を転換した。そ のための遺伝子源としては，耐性型プロトックスを持つと いうことから，ETR-245 株を選んだ．耐性型プロトックス 遺伝子を単離するため，まず，基本である野生型プロトッ クス cDNA の塩基配列を解明し，その塩基配列情報を利用 してPCR を行うというストラテジーを立てた.

\section{遺伝的相補法}

プロトックス cDNA の単離を目指した 1994 年には真核 生物のプロトックス cDNA は単離されておらず，大腸菌 ${ }^{22)}$ と枯草菌 ${ }^{23)}$ でのみプロトックス cDNA が単離されていた。 これら cDNA をプローブとしたハイブリダイゼーション によってタバコのプロトックス cDNA を単離する事を試 みたが，単離は不可能であった。1995 年になって大腸菌の プロトックス遺伝子欠損変異株を用いた遺伝的相補法に よってヒトのプロトックス cDNA を単離することに成功 したという研究が報告された ${ }^{24)}$.そこで大腸菌のプロトッ クス遺伝子欠損変異株を入手し（VSR800 株及びSASX38 株), 遺伝的相補法によって独自に夕バコのプロトックス cDNA を単離することを試みた。遺伝的相補法の原理を以 下に示す. 大腸菌ではプロトックス遺伝子は hem $G$ という 遺伝子によってコードされているが, 野生株では hemG 遺 
伝子から HemG タンパク質（プロトックス）が発現され, この働きによってへムが合成され，正常に生育する。一方， hem $G$ 遺伝子欠損変異株では HemG が発現されず，ほとん ど生育することができない. それに対し, hemG 遺伝子欠損 変異株に植物の cDNA ライブラリーを加之, その中に植物 のプロトックス cDNA が存在すれば, 植物のプロトックス cDNA から植物のプロトックスが発現され，その働きに よってへムが合成され，生育が回復する。

\section{野生型プロトックス cDNA の性質}

遺伝的相補法によってタバコ栽培品種 SR-1 から配列の 大きく異なった 2 種の野生型プロトックス cDNAを単離 し, 全塩基配列を解明した。これらを NtPX-1 及び NtPX-2 と名付けた。これら配列を公表するより先に, Lermontova らによってタバコ栽培品種サムソン $\mathrm{NN}$ から単離した 2 種類のプロトックス cDNA の塩基配列が報告され ${ }^{25)}$, これ ら遺伝子産物の細胞内における局在性も解明された。そこ で, 得られた配列を Lermontova らの配列と比較した結果, NtPX-1 は葉緑体型のプロトックス, NtPX-2 はミトコンド リア型のプロトックスであることが明らかとなったが, 塩 基配列に数力所の変異が認められた。

\section{ETR-245 株からのプロトックス cDNA の単離}

ETR-245 株及び感受性株から mRNA を抽出し, タバコ 野生型プロトックス cDNA の塩基配列情報からデザイン したオープンリーディングフレーム增幅用プライマーに よってRT-PCR を行い, プロトックス cDNA を増幅した。 増幅した cDNAをTA-クローニング法によって発現べク ターpCR2.1にlacZ 遺伝子と読み枠が合致するようにサ ブクローニングした，得られたプラスミドを，感受性株由 来のミトコンドリア型プロトックス cDNA を保持するも のを pCR-HM，ETR-245 株由来のミトコンドリア型プロ トックス cDNA を保持するものを pCR-RM, 感受性株由 来の葉緑体型プロトックス cDNA を保持するものを pCRHC 及び ETR-245 株由来の葉緑体型プロトックス cDNA を保持するものを pCR-RC とそれぞれ名付けた。これらプ ラスミドを大腸菌のプロトックス遺伝子欠損変異株に導入 したところ, lacZ 遺伝子の発現を誘導しなくとも（リー キーに), 生育が回復した。

\section{各プロトックス遺伝子産物の ET-751 感受性}

これらプロトックス遺伝子産物の ET-751に対する感受 性を比較する方法として, 当初は, 大腸菌内で cDNA から 発現されたプロトックスを抽出し酵素活性を測定すること を試みたが, 活性を保持する酵素を抽出することは困難で あった，そこで，各プロトックス cDNAによって生育を相 補された大腸菌のプロトックス遺伝子欠損変異株の生育に
Table 4 Sensitivity of the Protox gene products to ET-751 measured as the inhibitory effect on the growth of the $E$. coli complemented with the Protox cDNAs.

\begin{tabular}{|c|c|c|}
\hline E. coli & $\mathrm{I}_{50}$ of ET-751 (nM) & $\mathrm{R} / \mathrm{S}$ ratio \\
\hline SASX38(pCR-HM $\left.{ }^{a}\right)$ & 70 & \multirow{3}{*}{$1.3^{\mathrm{e})}$} \\
\hline & & \\
\hline SASX38(pCR-RM $\left.{ }^{b)}\right)$ & 90 & \\
\hline SASX38(pCR-HC $\left.{ }^{c}\right)$ & 2.5 & \multirow{3}{*}{$>4000^{f)}$} \\
\hline & & \\
\hline SASX38(pCR-RC $\left.{ }^{d}\right)$ & $>10,000$ & \\
\hline
\end{tabular}

a) The plasmid with mitochondrial Protox cDNA from normal cells. b) The plasmid with mitochondrial Protox cDNA from ETR-245 cells. ${ }^{c}$ The plasmid with chloroplastic Protox cDNA from normal cells. d) The plasmid with chloroplastic Protox cDNA from ETR-245 cells. e) b)/a). if) d) / c).

対するET-751の阻害効果を測定することを試みた．大腸 菌としては, プロトックス遺伝子欠損変異株 SASX38 株に 植物のプロトックス cDNAを含む 4 種のプラスミド (pCR-HM，pCR-RM，pCR-HC 及び pCR-RC)のいずれか を導入したものを用いた。このような大腸菌はプロトック スに関しては植物であると考えられる。これら大腸菌の懸 濁液を 0 から高濃度の ET-751 を含む液体培地に接種し, $28^{\circ} \mathrm{C}, 30$ 時間前後, 振とう培養した. 遺伝子産物が ET-751 に対して感受性が高い場合, 高濃度の ET-751を含む培地 では大腸菌の生育が抑制された。そこで, 培養した大腸菌 の吸光度を測定し, 大腸菌の生育に対する ET-751 の $\mathrm{I}_{50}$ 值 を測定した。

その結果 (Table 4)，ミトコンドリア型プロトックス cDNAの遺伝子産物に関しては, 感受性株由来のもので ET-751 に対する $\mathrm{I}_{50}$ 值が $70 \mathrm{nM}$, ETR-245 株由来のもので $90 \mathrm{nM}$ となり, 感受性に大きな違いは認められなかった。一 方, 葉緑体型プロトックス cDNAの遺伝子産物に関して は, 感受性株由来のもので $\mathrm{I}_{50}$ 值が $2.5 \mathrm{nM}$ であったが, ETR245 株由来のものでは $10,000 \mathrm{~nm}$ 以上となり, R/S 比は 4000 以上となった。したがって，ETR-245 株における耐性 はミトコンドリア型ではなく葉緑体型プロトックスの耐性 型への変異に起因することが明らかとなった。 また, 従来 は，葉緑体型及びミトコンドリア型の両者がプロトックス 阻害型除草剤の標的酵素と考えられていたが26), ETR-245 株が葉緑体型プロトックスのみの耐性型への変異で耐性を 獲得していることから，ミトコンドリア型プロトックスは 無関係であり，葉緑体型プロトックスのみが標的酵素であ ることが明らかとなった。

\section{耐性型プロトックス遗伝子産物の交差耐性}

様々な構造のプロトックス阻害型除草剂に対する ETR245 株由来の耐性型遺伝子産物の交差耐性に関しても検討 
Table 5 Sensitivity of chloroplastic Protox gene products to several Protox inhibiting herbicides measured as the inhibitory effect on the growth of $E$. coli complemented with each Protox cDNA.

\begin{tabular}{cccc}
\hline \multirow{2}{*}{ Herbicide } & \multicolumn{3}{c}{$\mathrm{I}_{50}(\mathrm{nM})$} \\
\cline { 2 - 4 } & $\mathrm{SASX38}\left(\mathrm{pCR}-\mathrm{HC}^{\mathrm{a}}\right)$ & $\mathrm{SASX38}\left(\mathrm{pCR}-\mathrm{RC}^{\mathrm{b}}\right)$ & $\mathrm{R} / \mathrm{S} \mathrm{ratio}^{\mathrm{c}}$ \\
\hline Oxadiazon & 550 & $>100,000$ & $>180$ \\
S-23142 $^{\mathrm{d})}$ & 2.5 & 1,400 & 560 \\
Acifluorfen $^{2}$ & 1800 & 17,000 & 9.4 \\
\hline
\end{tabular}

a) The plasmid with chloroplastic Protox cDNA from normal cells. b) The plasmid with chloroplastic Protox cDNA from ETR-245 cells. c) b)/a). d) See the text.

した. 除草剤としてはオキサジアゾール系の oxadiazon, フ タルイミド系の S-23142( $N$-[4-chloro-2-fluoro-5-propagyloxy]-phenyl-3,4,5,6-tetrahydrophthalimide) 及びジフェニル エーテル系の acifluorfen を用いた。 その結果 (Table 5), い ずれの除草剤に対しても高い交差耐性を示したが, ET-751 に対する耐性が最も高く, acifluorfenに対しては比較的耐 性が低いことが明らかとなった。

\section{耐性型プロトックス cDNA の塩基配列解析}

ETR-245 株由来の耐性型プロトックス cDNAにおける 変異部位を解明するため, 感受性株由来の pCR-HC 及び ETR-245株由来のpCR-RC中におけるプロトックス cDNAの塩基配列を解明することを試みた．その結果， pCR-HCにおける塩基配列は夕バコ野生型プロトックス cDNA（NtPX-1）と全く同一の配列であったが, pCR-RC には一塩基のみが変異した点突然変異が 1 か所認められた (Fig. 4). 塩基番号 717 に相当する塩基 C (シトシン) が $\mathrm{T}$ (チミン)に変異し, その結果, 231 番目のコドンが GCT か ら GTT に変異し, 最終的に 231 番目のアミノ酸が $\mathrm{Ala}(ア$ ラニン）から Val (バリン) に変異していた．部位特異的突 然変異法によって pCR-HCに同様の突然変異を導入した ところ感受性型から耐性型に変化したことから（データ未 掲載)，この変異が ETR-245 株における耐性の原因である
ことが明らかとなった。また，プロトックス阻害型除草剂 はプロトックスにおけるこの部位，あるいは近傍に結合す ることも示唆された。 さらに,プロトックス阻害型除草㘊は プロトックスの競合的阻害剂であるため ${ }^{27,28)}$ ，プロトック スの基質であるProtogenもこの部位，あるいは近傍に結合 することが示唆された. ダイズ29)や夕バコ年) でも耐性型プ ロトックスが知られており，これらにおける変異部位を同 定することによって，プロトックス阻害型除草凨及び基質 の結合部位, 両者の相互作用を分子レベルで解明すること が可能であろう.また, プロトックス遺伝子に部位特異的突 然変異を導入し，プロトックス阻害型除草剂に対する感受 性を検討することによっても，同様の解析が可能となろう。

\section{耐性型プロトックス cDNA の植物体における発現 ${ }^{31)}$}

ETR-245 株由来の耐性型プロトックス cDNA を pBI 系 のバイナリーベクター中におけるCaMV 35S プロモー ターの下流に㨂入し，アグロバクテリウム法によってタバ コ野生株に導入した。得られた形質転換植物から調製した リーフディスクを薬液に浸漬し, ET-751に対し高い耐性を 示す系統を選抜した。選抜された T1-7 系統を用いて whole plantに対する薬剤散布試験を行ったところ, 対照の非形質 転換植物が完全に枯死する $20 \mathrm{~g}$ a.i./ha の ET-751 を散布し ても，薬害はほとんど認められなかった(Fig. 5)。したがっ て，本耐性遺伝子を植物に導入することによってプロトッ クス阻害型除草剂耐性植物を作出する事が可能であること が明らかとなった。

\section{おわりに}

本研究の結果, ETR-245 株由来の耐性型プロトックス遺 伝子産物がいずれのプロトックス阻害型除草剤に対しても 高い耐性を示し，かつ, ET-751に対して最も高い耐性を示 すことが明らかとなった。ささらに，本耐性遺伝子を植物体 で発現させたところ植物体レベルでも高い耐性を示したこ とから，本耐性遺伝子はプロトックス阻害型除草剂耐性植 物の作出に有用であると考之られた．今後は，形質転換植

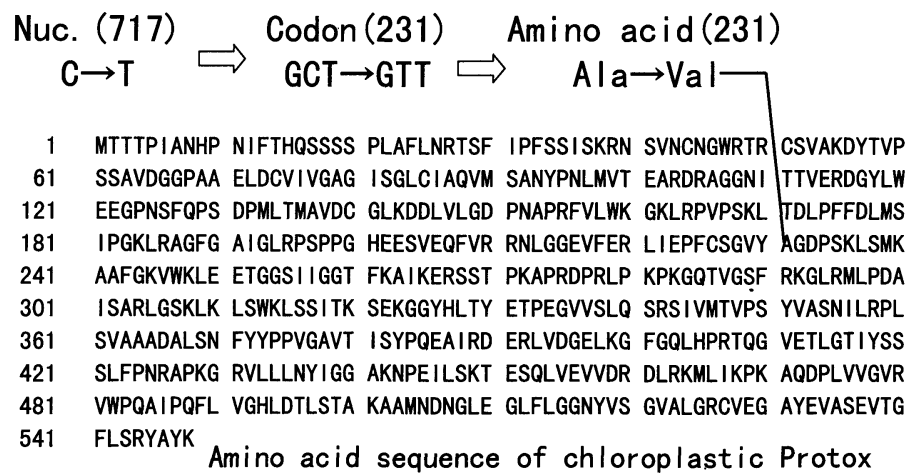

Fig. 4 Sequence analysis of resistant Protox cDNA in pCR-RC from ETR-245. 


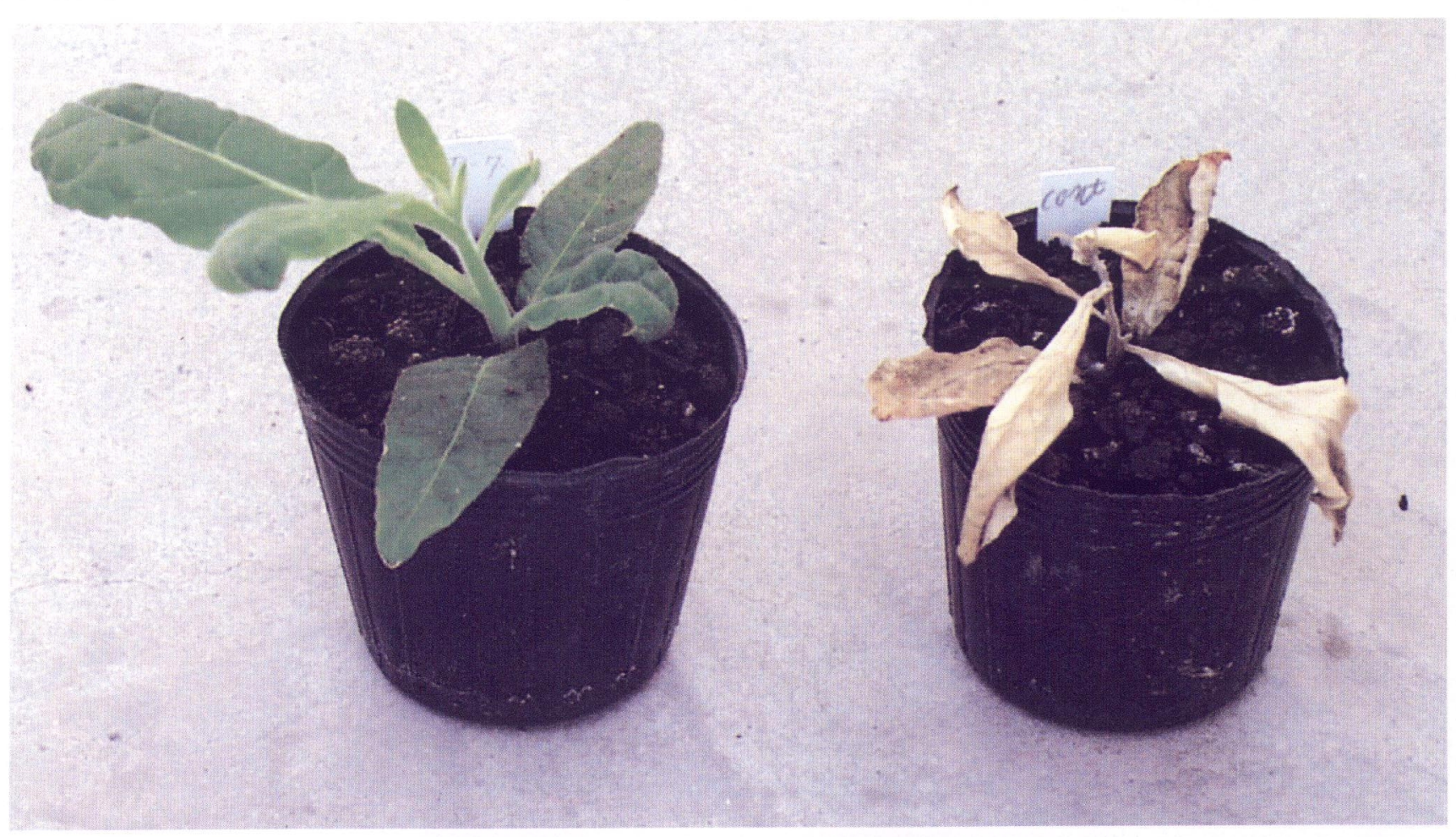

Fig. 5 Resistance in transformed tobacco plant sprayed with ET-751 (2\% SC) at the dose rate of $20 \mathrm{~g}$ a.i./ha. The photograph was taken at 10 days after treatment. Left: T1-7 line transformed with the resistant Protox cDNA from ETR-245. Right: non-transformed plant.

物における耐性の遺伝様式, 夕バコ以外の植物における発 現及び耐性, より強力なプロモーターによる発現, 形質転 換植物の生育ステージと耐性等を検討し, 本耐性遺伝子に よる形質転換植物と ET-751 という組み合わせの実用化を 目指し,さらに, 研究を進めていきたい.

本研究を遂行するにあたり, 日本農薬(株)の多くの方々にお 世話になりました。この場を借りて，深く感謝の意を表します。 また, 大腸菌プロトックス遺伝子欠損変異株 VSR800 株を譲渡 して頂いた京都大学の井口八郎博士，大腸菌プロトックス遺伝 子欠損変異株 SASX38 株を譲渡して頂いたモントリオール大 学の A. Sasarman 博士に深く感謝致します.

\section{引用 文 献}

1) M. Matringe \& R. Scalla: Plant Physiol. 86, 619 (1988)

2) M. Matringe, J. M. Camadro, P. Labbe \& R. Scalla: Biochem. J. 260, 231 (1989)

3) D. A. Witkowski \& B. P. Halling: Plant Physiol. 90, 1239 (1989)

4) J. M. Jacobs, J. M. Wehner \& N. J. Jacobs: Pestic. Biochem. Physiol. 50, 23 (1994)

5) H. J. Lee \& S. O. Duke: J. Agric. Food Chem. 42, 2610 (1994)

6) S. Matsunaka: J. Agric. Food Chem. 17, 171 (1969)

7) P. Böger \& K. Wakabayashi: Z. Naturforsch. 50, 159 (1995)

8) Y. Miura, M. Ohnishi, T. Mabuchi \& I. Yanai: "Proceedings 1993 Brighton Crop Protection Conference-Weeds," pp. $35-40,1993$

9) S. Murata, A. Yuda, A. Nakano, Y. Kimura, K. Motoba, T. Mabuchi, Y. Miura, H. Nishizawa \& S. Funayama: "Proceedings 1995 Brighton Crop Protection ConferenceWeeds," pp. 243-248, 1995

10) M. Horikoshi \& T. Hirooka: J. Pesticide Sci. 24, 13 (1999)

11) R. J. Smeda \& S. C. Weller: Weed Sci. 39, 497 (1991)

12) R. S. Chaleff \& T. B. Ray: Science 223, 1148 (1984)

13) S. R. Singer \& C. N. Mcdaniel: Plant Physiol. 78, 411 (1985)

14) D. L. Shaner \& P. C. Anderson: "Biotechnology in Plant Science," ed. by M. Zaitlin, P. R. Ray \& A. Hollander, Academic Press, New York, pp. 287-300, 1985

15) K. Y. Lee, J. Townsend, J. Tepperman, M. Black, C. F. Chui, B. Mazur, P. Dunsmuir \& J. Bedbrook: EMBO J. 7, 1241 (1988)

16) A. Pay, M. A. Smith, F. Nagy \& L. Marton: Nucleic Acids Res. 16, 8176 (1988)

17) H. Hirochika: EMBO J. 12, 2521 (1993)

18) P. Böger: J. Pesticide Sci. 22, 257 (1997)

19) I. Furusawa, K. Tanaka, P. Thanutong, A. Mizuguchi, M. Yazaki \& K. Asada: Plant Cell Physiol. 25, 1247 (1984)

20) C. Y. Yu \& J. B. Masiunas: Weed Sci. 40, 408 (1992)

21) M. Horikoshi, K. Mametsuka \& T. Hirooka: J. Pesticide Sci. 24, 17 (1999)

22) A. Sasarman, J. Letowski \& G. Czaika: Can. J. Microbiol. 39, 1155 (1993)

23) T. A. Dailey, P. Meissner \& H. A. Dailey: J. Biol. Chem. 269, 813 (1994)

24) K. Nishimura, S. Taketani \& H. Inokuchi: J. Biol. Chem. 
270, 8076 (1995)

25) I. Lermontova, E. Kuruse, H.-P. Mock \& B. Grimm: Proc. Natl. Acad. Sci. USA 94, 8895 (1997)

26) M. Matringe, J. M. Camadro \& N. Brouillet: "Proceedings 1993 Brighton Crop Protection Conference-Weeds," pp. 703-712, 1993

27) M. Matringe, R. Mornet \& R. Scalla: Eur. J. Biochem. 209, 861 (1992)

28) R. Varsano, M. Matringe, N. Magnin, R. Mornet \& R. Scalla: FEBS Lett. 272, 106 (1990)

29) T. Pornprom, H. Matsumoto, K. Usui \& K. Ishizuka:
Pestic. Biochem. Physiol. 50, 107 (1994)

30) K. Ichinose, F. S. Che, Y. Kimura, A. Matsunobu, F. Sato \& S. Yoshida: J. Plant Physiol. 146, 693 (1995)

31) 豆塚弘毅・堀越 守・大塚 隆・廣岡 卓：日本農薬学会 第 24 回大会講演要旨集, p. 58,1999

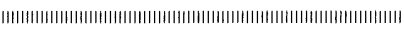

Society Awards 1999

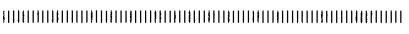

(on high prospectiveness)

\section{Fundamental Studies on the Production of Plants Resistant to Protox Inhibiting Herbicides}

In 1989, Nihon Nohyaku Co., Ltd. was in the process of developing the promising herbicide, ET-751, which belonged to Protox inhibiting herbicides. At that time, a resistant gene against the Protox inhibiting herbicides had not been isolated from plants. Therefore, the research target was focused on the selection of the resistant cell line to the herbicides as the first step for the production of plants resistant to the herbicides.

The application of Protox inhibiting herbicides to plant leads to the peroxidative destruction of cellular membrane and bleaching of tissues in the presence of light. In treated tissues, these herbicides cause the accumulation of protoporphyrin IX (Proto IX) known as a strong photosensitizer to generate singlet oxygen. Then, further research revealed that the target enzyme of Protox inhibiting herbicides was protoporphyrinogen oxidase (Protox), which catalyzes the oxidation of protoporphyrinogen IX (Protogen) to Proto IX, the final common precursor in the heme and chlorophyll synthesis. From these characteristics, the herbicides are also designated as photobleaching or peroxidizing herbicides.

ET-62311 4-chloro-3-[2,4-dichloro-5-(2-propenyloxy) phenyl]-5-difluoromethoxy-1-methylpyrazole], one of the 3-phenylpyrazole with a Protox inhibiting herbicidal activity synthesized in Nihon Nohyaku Co., Ltd. was used for the cell line selection. ET-751 (pyraflufenethyl, Fig. 1 and Table 1), a derivative of ET-62311 with the same activity was also used for later experiments. ET-751 is now registered as Ecopart ${ }^{\circledR}$ for the cereal market.

Plant cell and tissue culture techniques are useful tools to produce herbicide resistant plants, because, in general, a plant cell has the ability to regenerate a whole plant and cultured plant cells are genetically variable. Various herbicide resistant cell lines were selected by the techniques and in some cases resistant plants were regenerated. Herbicide resistant cell lines are also useful as the genetic resources for the herbicide resistant genes. From these viewpoints, we tried to select tobacco cell lines resistant to Protox inhibiting herbicides.

Tobacco calli were regenerated from protoplasts and the selection was started using medium containing $20 \mathrm{nM}$ ET-62311 (Table 2), twice as high as MIC (10 nM). The selection was further repeated by the stepwise increase of the concentration of ET-62311. Thirty-six cell lines could grow on the medium containing $2400 \mathrm{nM}$ ET62311 after selection for 16 months. Three cell lines of rapid growth were selected and designated as ETR-056, 245 and 253. Regeneration of these cell lines was unsuccessful.

The amount of Proto IX accumulated in normal cells, ETR-056, 245 and 253 were measured periodically after ET-62311 treatment (Fig. 2). The amount of Proto IX increased in normal cells and especially ETR-056. On the other hand, no Proto IX accumulation was observed for ETR-245 and 253.

Each resistant cell line was cross-resistant to three Protox inhibiting herbicides tested, including ET-751 (Table 3). In addition, ETR-056 was cross-resistant to paraquat. ETR-253 was cross-resistant to several herbicides with different modes of action. The resistance of ETR-245 was specific to Protox inhibiting herbicides. These results suggested the involvement of the overexpression of detoxifying enzymes for superoxide species in ETR-056 and the multiple resistance due to a reduced uptake and/or an enhanced metabolism of herbicides in 
ETR-253. In ETR-245, the overexpression of Protox or the alteration of Protox to the resistant form might confer the resistance.

In order to analyze the resistant mechanism in ETR245 , crude Protox fractions were extracted from normal cells and ETR-245, and the Protox activity was measured in vitro. The specific activity in each fraction was almost equivalent, 2.24 and $2.93 \mathrm{~nm}$ Proto IX $/ \mathrm{min} / \mathrm{mg}$ protein for normal cells and ETR-245, respectively. The inhibitory effect of ET-751 on each Protox activity was also examined in vitro (Fig. 3). $I_{50}$ values of ET-751 against Protox activity from normal cells and ETR-245 were 48 and more than $5000 \mathrm{nM}$, respectively. Thus, Protox enzyme from ETR-245 was more than 100-fold resistant than that from normal cells. These results suggested that the alteration of the Protox enzyme to the resistant form would be the cause for the resistance in ETR-245.

The isolation of a resistant gene from a resistant cell line and transformation of plants with the gene was necessary to express resistance in a whole plant, because the regeneration of resistant cell lines was unsuccessful. ETR-245 was used as the genetic resource for the resistant gene, because ETR-245 had the mutant Protox resistant to Protox inhibiting herbicides.

When we tried to isolate the resistant protox gene from ETR-245, no sequence information about eucaryotic Protox gene except procaryotic one was available. Although we tried hybridization using these procaryotic genes as probes, tobacco Protox cDNA could not be isolated. In 1995, the isolation of human Protox cDNA by genetic complementation using $E$. coli mutant defective in Protox was reported. Therefore, we obtained the E. coli mutant (VSR800 and SASX38) and isolated at first wild-type tobacco Protox cDNA from tobacco leaves by the method by ourselves. The sequences of wild-type Protox cDNAs thus derived were almost the same as the sequence of tobacco Protox cDNA recently reported, though some differences were observed.

Using the sequence information, Protox cDNAs were amplified from normal cells and ETR-245, and subcloned into $\mathrm{pCR}^{\mathrm{TM}} 2.1$ in frame with lacZ gene. The plasmids with mitochondrial Protox cDNAs from normal cells and ETR-245 were designated as pCR-HM and pCR-RM, respectively. The plasmids with chloroplastic Protox cDNAs from normal cells and ETR-245 were designated as pCR-HC and pCR-RC, respectively. Each plasmid was introduced into E. coli SASX38 and confirmed to complement the poor growth of the E. coli.

The sensitivity of each Protox gene product to ET-751 was compared by measuring the inhibitory effect of ET-751 on the growth of $E$. coli SASX38 complemented with plant Protox cDNAs (Table 4), because the extraction of the active Protox enzyme expressed in $E$. coli was rather difficult. $\mathrm{I}_{50}$ values of ET-751 for $E$. coli SASX38
(pCR-HM and pCR-RM) were 70 and $90 \mathrm{nM}$, respectively, indicating that both gene products were similarly sensitive to ET-751. $\mathrm{I}_{50}$ values for $E$. coli SASX38 (pCR-HC and pCR-RC) were 2.5 and more than 10,000 $\mathrm{nM}$, respectively, indicating that the gene product encoded by the Protox cDNA from ETR-245 was more than 4000 -fold resistant than that from normal cells. It was clarified from these results that the resistance in ETR-245 was caused by the alteration of the chloroplastic Protox gene product from the sensitive form to the resistant one. As the alteration of the mitochondrial one was not necessary for the resistance, it was suggested that the target enzyme of the herbicides would not be both Protox but solely the chloroplastic one.

Cross-resistance of the resistant Protox gene product encoded by pCR-RC to other Protox inhibiting herbicides such as oxadiazon, S-23142 ( $N$-[4-chloro-2-fluoro5-propagyloxy]-phenyl-3,4,5,6-tetrahydrophthalimide) and acifluorfen was also evaluated (Table 5). The resistant gene product exhibited high resistance to all the herbicides tested. The resistance was highest for ET751, whereas rather low for acifluorfen, the diphenyl ether herbicide.

Nucleotide sequences of sensitive and resistant chloroplastic Protox cDNAs in pCR-HC and pCR-RC, respectively, were compared. The cDNA in pCR-HC was identical to wild-type Protox cDNA from tobacco leaves. On the other hand, single-point mutation was observed for the cDNA in pCR-RC (Fig. 4). The codon corresponding to amino acid 231 was mutated from GCT to GTT, which resulted in the substitution of alanine for valine. When the same single-point mutation was introduced into pCR-HC, the gene product was converted from the sensitive form to the resistant one, reconfirming that this mutation was the cause for the resistance in ETR-245. From these results, it was suggested that Protox inhibiting herbicides would bind at or near this mutation site in Protox enzyme. Because the herbicides are competitive inhibitors of Protox, the substrate of Protox, i.e. Protogen, would also bind at or near this mutation site. Further study using other resistant Protox enzymes would reveal the binding site and interaction of the herbicides and the substrate.

The resistant Protox cDNA from ETR-245 was introduced into tobacco plants by Agrobacteriummediated transformation and expressed under the control of CaMV 35S promoter. The transformed plants highly resistant to ET-751 were selected by the leaf disc assay. When the whole plant of T1-7 line thus selected was sprayed with ET-751 at the dose rate of $20 \mathrm{~g}$ a.i./ha, at which non-transformed plants were completely killed, no injury was observed (Fig. 5). Therefore, the resistant Protox gene from ETR-245 in this research would be valuable for the production of plants resistant to Protox inhibiting herbicides. 